\title{
Seed production and juvenile rearing of the tropical abalone Haliotis varia Linnaeus 1758
}

\author{
T.M. Najmudeen*, A.C.C. Victor \\ Central Marine Fisheries Research Institute, (Indian Council of Agricultural Research), P.B. No.1603, \\ Tatapuram P.O., Cochin-14, Kerala, India
}

Received 20 August 2003; received in revised form 28 November 2003; accepted 2 December 2003

\begin{abstract}
Spawning, larval and juvenile rearing of the tropical abalone Haliotis varia L. were studied. Brood stock abalone were induced to spawn by exposure to air for $2 \mathrm{~h}$ at $27{ }^{\circ} \mathrm{C}$. Female abalone spawned a mean of 76,530 eggs. Fertilised eggs measured $180 \mu \mathrm{m}$ in diameter. Seventy percent survival was obtained during larval rearing. Larvae passed trochophore, veliger, gliding and creeping stages and were induced to settle on a mat of diatoms containing Nitszchia sp. and Navicula sp. The larval rearing period of $H$. varia ranged from 4 to 6 days at $27^{\circ} \mathrm{C}$. The settled spat vigorously fed on the diatom mat until the 50th day of postfertilisation and coralline red algal film, until the 70th day of postfertilisation. First respiratory pore was formed on the 27th day of postfertilisation. Juvenile abalones were reared on three algal diets such as coralline red algae, green filamentous algae and Ulva lactuca from the 71st to 200th day of postfertilisation. Those fed with coralline algae showed best and consistent growth. Shell colour of juveniles was affected by diet. The present study on the production of juveniles in the hatchery is a baseline information to initiate abalone aquaculture in India and to help augment the natural population.
\end{abstract}

(C) 2004 Elsevier B.V. All rights reserved.

Keywords: Tropical abalone; Haliotis varia; Larval rearing; Seed production; Juvenile rearing; Benthic diatom

\section{Introduction}

Abalones enjoy a worldwide distribution and are known for their delicate meat that fetches a high international market value. In India, abalones are represented by only

* Corresponding author. Theparambil House, Lokamaleswaram, Kodungallur, Thrissur Dt., Pin-680 664 , Kerala, India. Tel.: +91-2-480 806572 (Res), +91-9447233910 (Mobile).

E-mail address: najmudeentm@yahoo.com (T.M. Najmudeen). 
one species, Haliotis varia, which grows to a maximum shell length of $80 \mathrm{~mm}$ (Fig. 1). The distribution of $H$. varia in the country is restricted to the Pamban and Tuticorin areas along the Gulf of Mannar and the Andaman and Nicobar Islands. Abalone does not support any commercial fishery in India because of its limited distribution and small size. Pioneering attempts have been made in recent years to study the larval rearing and reproduction in $H$. varia (Najmudeen et al., 2000; Najmudeen, 2001; Najmudeen and Victor, 2003).

Most of the other commercially important species of abalone have been successfully cultured and their 'larval development', documented (Ino, 1952; Leighton, 1972). Extensive literature are available on the spawning and larval rearing of the temperate species of abalone in the last two decades (Du and Guo, 1981; Tong, 1982; Baudry, 1982; Nie et al., 1984; Pena, 1984; Ebert and Houk, 1984; Tong et al., 1987; Genade et al., 1988; Iang et al., 1992). Although there is a high demand for cocktail-size tropical abalones in the international market (Chen, 1989), intensive efforts for their propagation have been initiated only recently (Jarayabhand et al., 1995; Capinpin and Hosoya, 1995; Jarayabhand and Paphavasit, 1996). No successful rearing of $H$. varia has been reported to date.

Abalone larvae depend on recognition of external chemical signals from the environment for settlement and metamorphosis (Morse et al., 1979; Morse and Morse, 1984). Substances such as $\gamma$-amino butyric acid (GABA; Morse, 1990), biotic films derived from seawater or mucus trails of grazing adult are used to induce metamorphosis (Seki and Kan-no, 1981; Toole, 1988; Hahn, 1989). As benthic diatoms form principal food source of postlarval abalone (Kawamura, 1996), maintaining a suitable diatom film is a critical factor in the success of abalone hatcheries worldwide.

Because abalone occupies a significant position in the world aquaculture scenario, it is imperative to develop its culture techniques in India with the native species. The

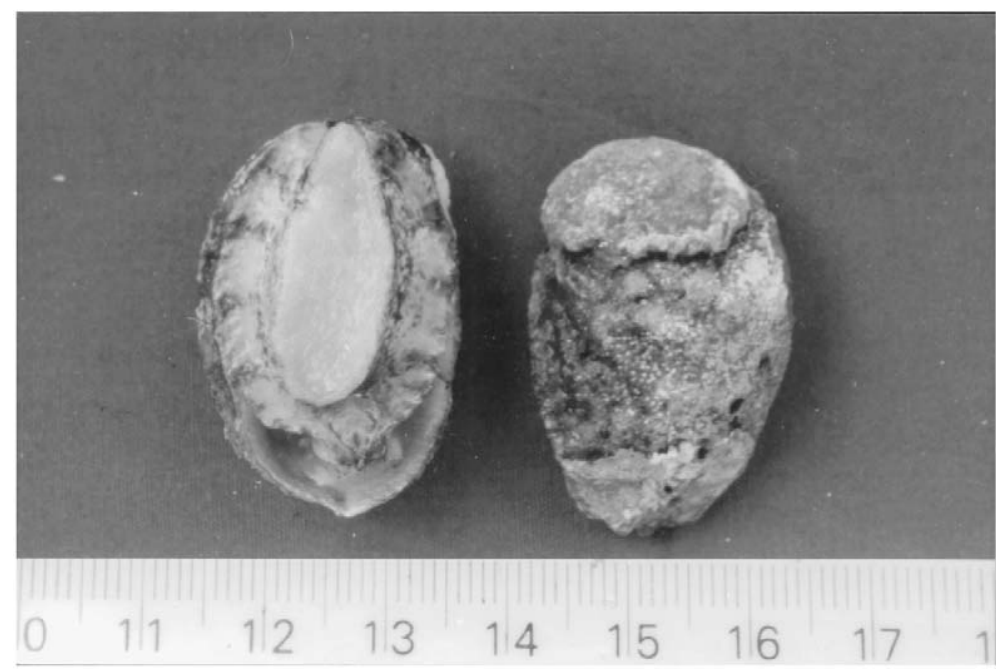

Fig. 1. Adult H. varia collected from the Gulf of Mannar. 
restricted and moderate distribution of this species in the country necessitates its production through aquaculture. Because the standardisation of seed production is the first step in attempting culture of a new species, the present investigation has focussed on the spawning, larval development and juvenile rearing of $H$. varia under controlled and semicontrolled conditions.

\section{Materials and methods}

\subsection{Brood stock maintenance}

Mature live specimens of $H$. varia of more than $25 \mathrm{~mm}$ in shell length were collected from the intertidal rocks of the Tuticorin Harbour basin, 2-3 days prior to full moon and new moon days. Care was taken not to damage the foot while dislodging them from the substratum with the aid of a wooden chisel. These were then transported to the Mandapam Regional Centre Laboratory of the Central Marine Fisheries Research Institute, by placing them on a round perforated asbestos sheet in a bucket with a wet piece of mat made up of jute fibres. The transportation time was 6-8 $\mathrm{h}$ and they were kept moist by sprinkling seawater at frequent intervals. Transported abalones were stocked in 1.5-tonne capacity FRP tanks filled with clean, filtered seawater (FSW). The FSW was obtained by filtering the seawater through a mechanical filter made of coarse and fine sand, charcoal and cotton. Feeding was done twice a week with thin pieces of freshly collected seaweed Ulva lactuca. Abalones were fed at a rate of $10 \%$ of the body weight after removing the leftover feeds from the tank.

\subsection{Spawning inducement and fertilisation}

Induced spawning was attempted in abalone by the desiccation method described by Carlisle (1945). Ripe male and female abalone were exposed to air for $2 \mathrm{~h}$ and then transferred at a ratio of 1 male: 1 female to a plastic basin containing 301 of FSW of $32 \pm 2$ ppt salinity. Three spawning trials were conducted by placing six abalones in each container. Spawning occurred at late night or early morning hours when water temperature was about $25 \pm 2{ }^{\circ} \mathrm{C}$.

After the gametes were completely extruded from the gonad, the spawning containers were left undisturbed for $1 \mathrm{~h}$ to facilitate fertilisation. As the fertilised eggs settled at the bottom of the container, they were collected by siphoning out the bottom water through a $50-\mu \mathrm{m}$ sieve, followed by repeated washing with FSW to remove excess sperm. Fertilisation percentage in each trial was estimated by aliquot sampling (Ebert and Houk, 1984).

\subsection{Hatching and larval rearing}

Fertilised ova developed to the early veliger stage in the hatching container and congregated at the water surface. About two-thirds of the surface water of the 
hatching container was siphoned out to another container with 201 of FSW, while the rest of the water containing discharged egg membranes, faeces of adult abalone and unhatched eggs were discarded. For estimating larval density, uniform distribution was obtained by stirring with a glass pipette. Aliquot samples were taken and counted under a light microscope.

During larval development, water flow and aeration were stopped. Daily water exchange was done with FSW after siphoning the larvae on to a $50-\mu \mathrm{m}$ net. Larval development stages were recorded twice daily by microscopic examination, and different stages were photographed using a binocular compound microscope with a camera unit. To assess the growth of the larvae, the length of 40 larvae in the samples from each trial was measured under an ocular micrometer calibrated against a stage micrometer, in alternate days. The hydrographic parameters, such as salinity, water temperature, $\mathrm{pH}$ and dissolved oxygen of the rearing container, were recorded daily using standard seawater analysis procedures (Strickland and Parsons, 1968).

\subsection{Induced settlement and metamorphosis}

On day 4, the free-swimming larvae were transferred to 20-1 capacity settling containers having a thin, uniform layer of benthic diatoms. The settling containers were placed without aeration in a greenhouse with translucent plastic roofing. Water exchange was done twice daily after filtering the larvae through a $100-\mu \mathrm{m}$ mesh sieve.

After the settlement of the creeping larvae, they were thinned and introduced to other 20-1 capacity containers for metamorphosis. The settled spat were carefully removed from the settling container by using a thin paintbrush without anaesthetising them. The containers were covered $6 \mathrm{~h}$ a day with dark cotton cloth to regulate diatom growth. The percentage success of metamorphosis was estimated by counting the number of peristomeal shell stage abalones from the samples at regular intervals under a compound microscope.

\subsection{Juvenile rearing}

The metamorphosed spat were retained in the settling containers until they reached the juvenile stage with 1-2 respiratory pores. They were reared until 50 days postfertilisation on diatom feed. From the 50th to 70th day of postfertilisation, they were fed with thin films of coralline red algae attached to the coralline stones, which were collected from the natural habitat of adult abalone. On the 71st day of postfertilisation, juveniles were transferred to juvenile culture tanks with a 201 capacity. Three rearing trials were conducted using different types of supplementary feed such as fresh, thin pieces of Ulva lactuca, coralline red algae and green filamentous algae in separate containers. Feeds were provided at weekly intervals. Water exchange was done every 3 days with FSW. Juvenile growth, length and width of 30 abalones from each trial, was measured weekly to the nearest millimeter. Juveniles were reared up to 200 days postfertilisation. 


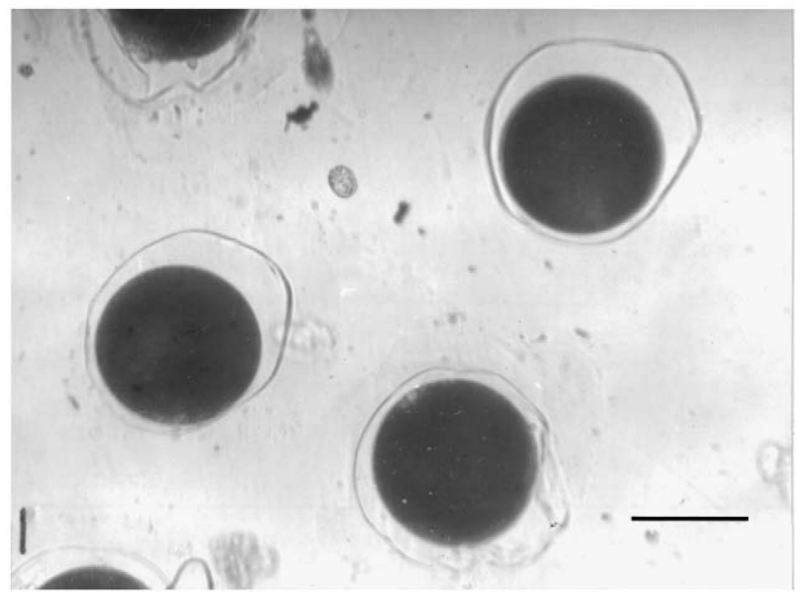

Fig. 2. Fertilised eggs of $H$. varia (bar $=100 \mu \mathrm{m})$.

\subsection{Diatom culture}

Culture of diatoms for the postlarval stage abalone commenced prior to larval settlement. Benthic diatoms, such as Nitzschia sp. and Navicula sp., scraped from the inner walls of the containers used to store seawater, were used as inoculum. Twenty litres of seawater in the larval rearing and settling containers enriched with Walne's (1974) algal culture medium was inoculated with diatom and kept in diffused sunlight without aeration. After 3-4 days, a uniform layer of diatoms was formed along the walls of the container. To keep the diatoms healthy, a water exchange was done on alternate days. Diatom subcultures were established regularly in order to transfer the postlarvae to new and healthy cultures at weekly intervals.

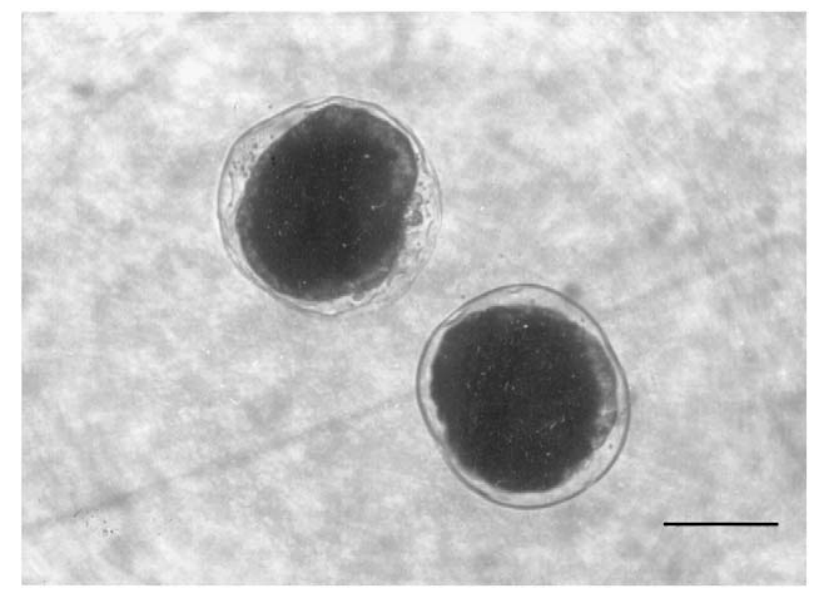

Fig. 3. Fully developed trochophore larva rotating inside the egg membrane (bar $=100 \mu \mathrm{m}$ ). 


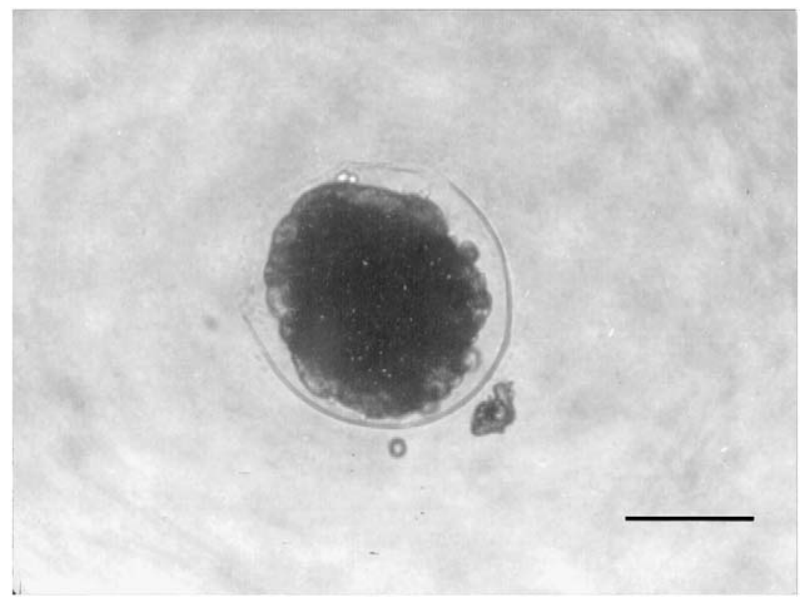

Fig. 4. Hatching of trochophore larva (bar $=100 \mu \mathrm{m})$.

Results of juvenile rearing under three feeding regimens were analysed by one-factor analysis of variance (ANOVA; Snedecor and Cochran, 1967). Differences were considered significant at $P<0.05$.

\section{Results}

\subsection{Brood stock management and spawning}

Abalones spawned at late night or early morning hours, when the temperature was around $25{ }^{\circ} \mathrm{C}$. The desiccation method was successful when the animals were fully

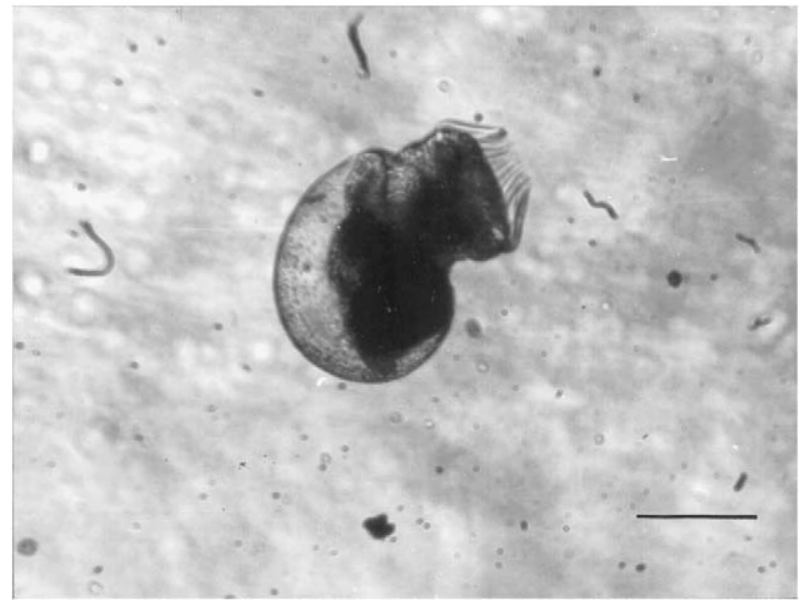

Fig. 5. Free-swimming early verliger larva $(\mathrm{bar}=100 \mu \mathrm{m})$. 


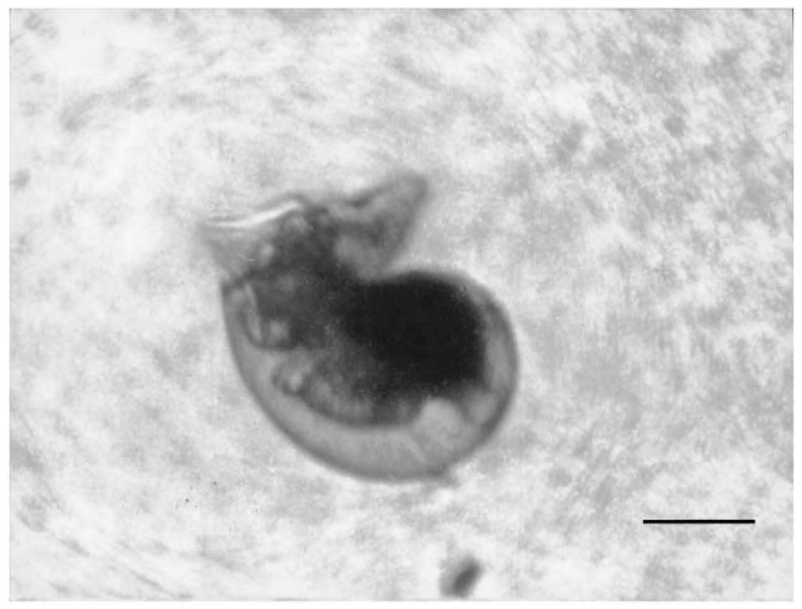

Fig. 6. Late veliger larva with extended velum $(\mathrm{bar}=100 \mu \mathrm{m})$.

mature. Males spawned first. The presence of sperm in the spawning container triggered females to spawn. Partial spawning was observed in some specimens, which were used for another spawning trial. Ejaculation of gametes was mainly through the last four respiratory pores. Sperm stayed in suspension.

The average number of eggs spawned was 76,530 per female with a maximum of 215,200 at a shell length of $48.23 \mathrm{~mm}$. Eggs were fertilised within $1 \mathrm{~h}$ of spawning. Fertilised eggs were $180 \mu \mathrm{m}$ in diameter and spherical in shape (Fig. 2). They immediately absorbed water and sank to the bottom. Excess sperm were found detrimental to hatching success. The average fertilisation rate was $50 \%$.

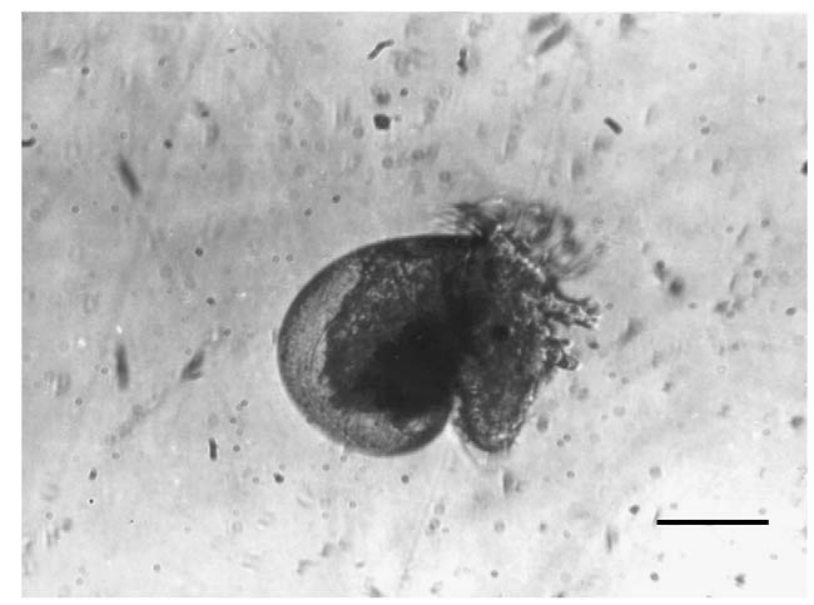

Fig. 7. Gliding larva with well-developed eyespots $(\mathrm{bar}=75 \mu \mathrm{m})$. 
Table 1

Optimum seawater parameters for rearing the larvae of $H$. varia

\begin{tabular}{lc}
\hline Parameter & Value (mean \pm S.D.) \\
\hline Temperature $\left({ }^{\circ} \mathrm{C}\right)$ & $26 \pm 2$ \\
Salinity $(\mathrm{ppt})$ & $33 \pm 2$ \\
$\mathrm{pH}$ & $8.3 \pm 0.3$ \\
Dissolved oxygen $(\mathrm{mg} / \mathrm{l})$ & $5.01 \pm 0.63$ \\
\hline
\end{tabular}

\subsection{Larval stages of $H$. varia}

The two-cell stage was reached within $2 \mathrm{~h}$ at $27{ }^{\circ} \mathrm{C}$. Trochophore stage larvae were obtained at about $10 \mathrm{~h}$ postfertilisation (Fig. 3) and hatching commenced at $12 \mathrm{~h}$. The average hatching rate was $70 \%$. The larvae began to rotate vigorously within the membrane, which resulted in the bursting of the membrane (Fig. 4). Free-swimming trochophore larvae were positively phototactic and had a tendency to gather at the culture surface. They measured about $190 \mu \mathrm{m}$ in diameter. The trochophore stage extended for $10-12 \mathrm{~h}$ at $27{ }^{\circ} \mathrm{C}$. At about $24 \mathrm{~h}$ postfertilisation, the early veliger stage ensued. The apical region of larvae became flat and the velum was completely developed with long cilia (Fig. 5). Larval shell covered the body just below the velum, and measured $210 \pm 12 \mu \mathrm{m}$ in length. In the late veliger larvae, the foot mass protrudes to the top of the shell and the larval shell is completely developed (Fig. 6). This stage extended to 3 days postfertilisation. On day 4, veliger larvae began to settle on the walls of the container but remained quite motile. The cephalic tentacles had four branches and well-developed eyespots (Fig. 7). Larvae could pull upright with their foot and also propel by ciliary action. This stage is found to be optimal for transferring to settling containers. Larvae actively crawled with their foot, but did not

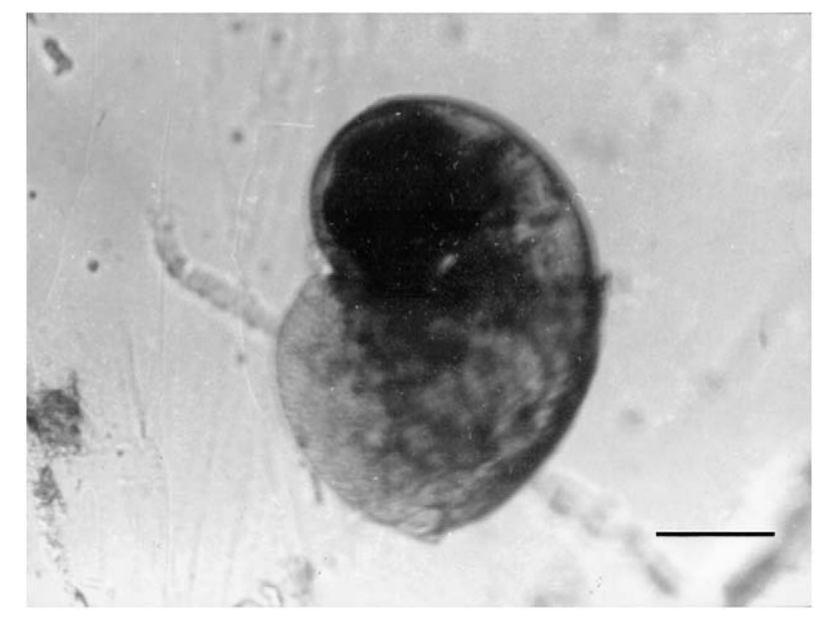

Fig. 8. Settled spat of $H$. varia $($ bar $=100 \mu \mathrm{m})$. 


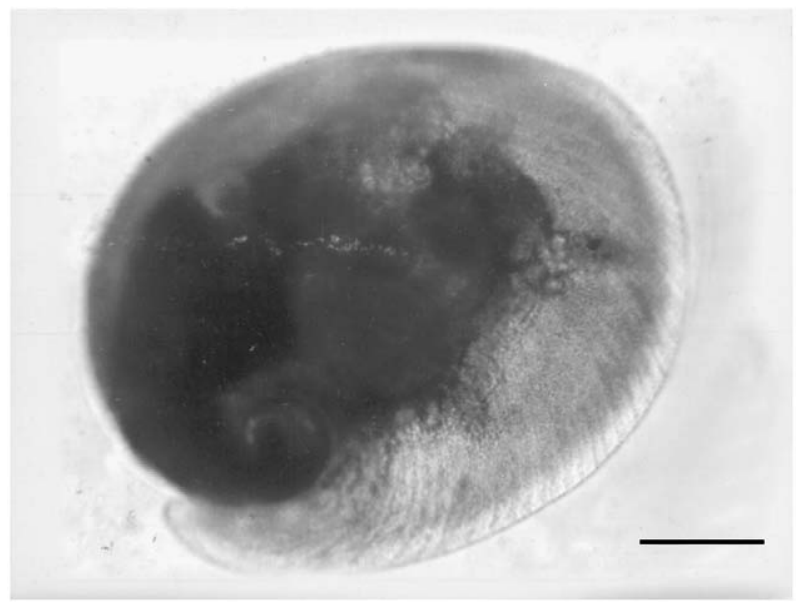

Fig. 9. Peristomeal growth stage of $H$. varia on the 6th day of postfertilisation $(\mathrm{bar}=100 \mu \mathrm{m})$.

stop swimming unless suitable settlement substratum was present. The creeping stage was fully obtained when the cilia were expelled and the abalones were dependent on benthic diatoms. Creeping larvae measured $260 \pm 12 \mu \mathrm{m}$ in length. The larval rearing period of $H$. varia ranged from 4 to 9 days at a water temperature of $27{ }^{\circ} \mathrm{C}$. No significant difference $(P>0.05)$ could be recorded in the water quality parameters between the three trials. The salinity for the larval rearing was $33 \pm 2 \mathrm{ppt}$ and the $\mathrm{pH}$ was $8.3 \pm 3$. The dissolved oxygen in the rearing containers was $5.01 \pm 0.63 \mathrm{mg} / \mathrm{l}$.

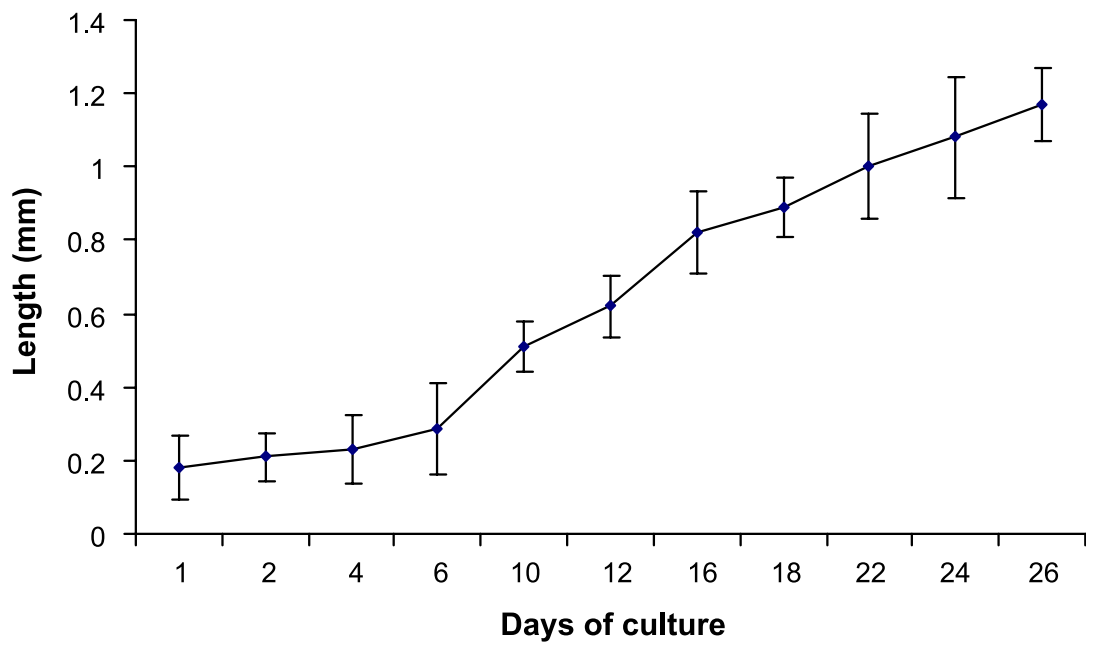

Fig. 10. Growth of larvae [length $(\mathrm{mm})]$ during larval and postlarval rearing period (vertical bars represent \pm S.D.). 


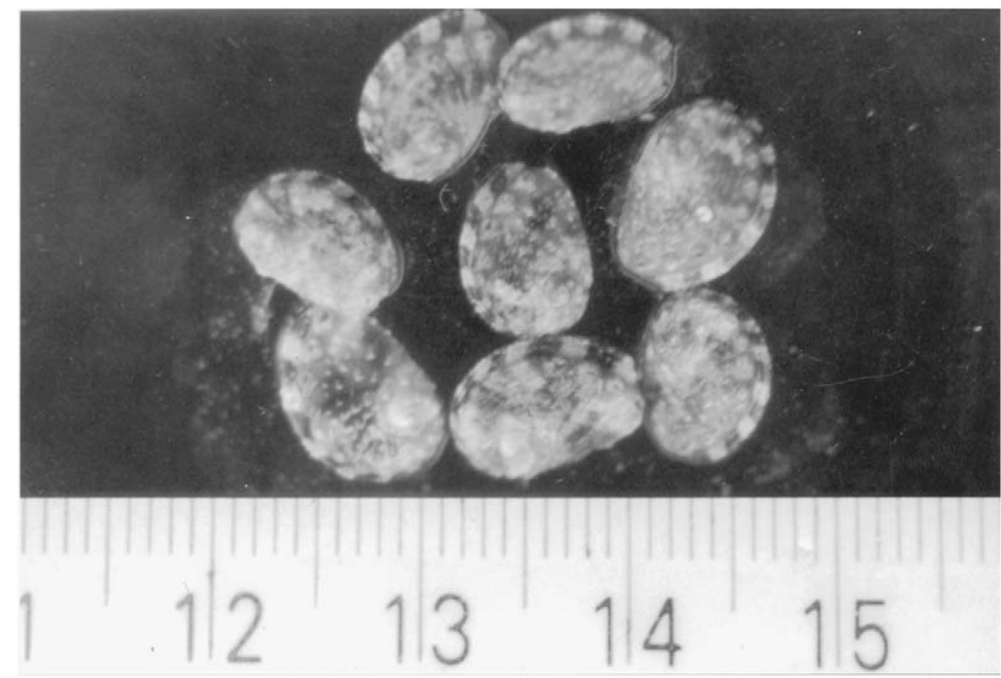

Fig. 11. Juveniles of $H$. varia fed with coralline red algae (46th day of postfertilisation).

Table 1 shows the mean value of the water quality parameters for the larval rearing of H. varia.

\subsection{Larval settlement and metamorphosis}

The majority of larvae ceased swimming and settled on the diatom film on the container walls. No settlement was observed on the bottom. After settlement, larvae never detached from the diatom surface. Complete settlement occurred at 7 days postfertilisation at $27{ }^{\circ} \mathrm{C}$. These abalones measured $288 \times 218 \mu \mathrm{m}$ (Fig. 8).

Peristomeal shell growth was first observed at 6 days postfertilisation resulting in the transformation of ovoid larval shell to the flat abalone shell form (Fig. 9). It was observed that the juvenile abalone actively fed on the diatom mat using their muscular foot. Shell growth was initially slow, but increased progressively (Fig. 10). On day 15, a violet shell colouration commenced and the juvenile abalone measured $820 \times 670 \mu \mathrm{m}$. The first respiratory pore was formed at the anterior end of the shell at a length of $2.2 \mathrm{~mm}$ at 26 days

Table 2

Survival rate of juveniles of $H$. varia reared under three different diets

\begin{tabular}{llll}
\hline Days of culture & \multicolumn{2}{l}{ Survival percentage } & Ulva lactuca \\
\cline { 2 - 4 } & Coralline red algae & Green filamentous algae & 100 \\
\hline 71 & 100 & 100 & 100 \\
105 & 89 & 77 & 100 \\
138 & 77 & 66 & 85 \\
170 & 75 & 64 & 80 \\
200 & 75 & 60 & \\
\hline
\end{tabular}




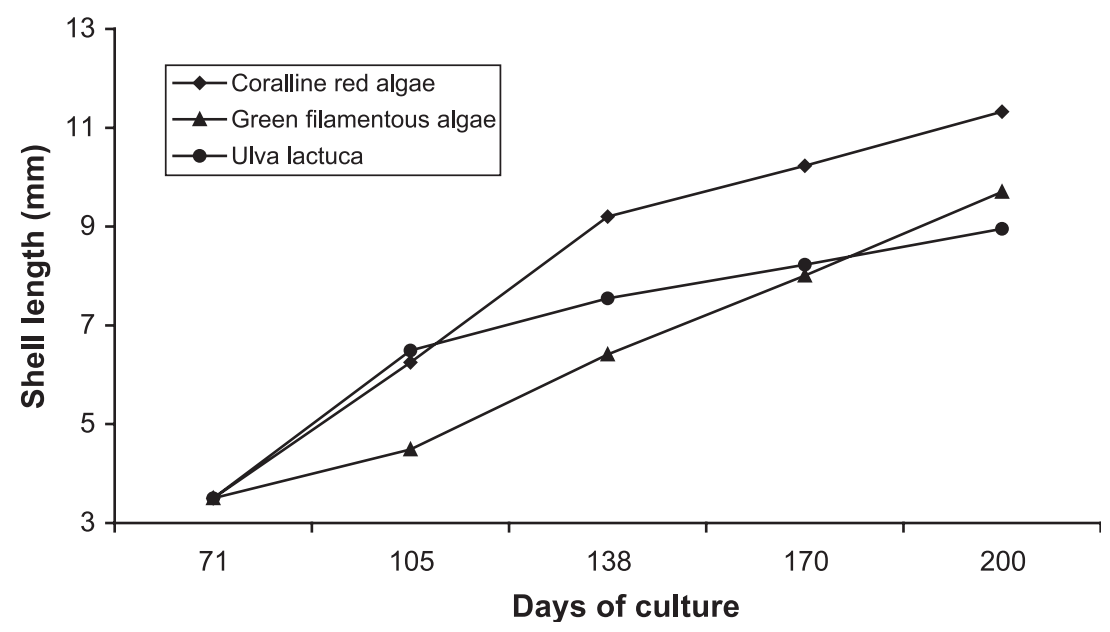

Fig. 12. Mean shell length $(\mathrm{mm})$ of $H$. varia juveniles fed with three different diets $(n=30 \times 3)$.

postfertilisation. Three respiratory pores were formed when the animal reached a shell length of $2.6 \mathrm{~mm}$ at 46 days postfertilisation (Fig. 11).

\subsection{Diatom culture}

A uniform thin layer of diatoms on the walls of the containers could be obtained after 4 days of culture. Fresh cultures could be initiated and sustained using the seawater from this container as inoculum. Overgrowth of green filamentous algae on the walls of the container was observed on exposure to sunlight for a long period.

\subsection{Juvenile rearing}

Supplemental feeding with fresh algae enhanced growth rates. Significant differences in growth rate were obtained between trials $(P<0.05)$. Average daily growth was higher for those fed with $U$. lactuca for the initial 35 days of culture. Survival rate was also higher in this trial (Table 2). After 200 days of rearing, mean shell lengths were 8.76 and $11.32 \mathrm{~mm}$, respectively, for juveniles fed with $U$. lactuca and coralline red algae (Fig. 12). Those fed with filamentous algae exhibited a poor growth rate of $29.15 \mu \mathrm{m}$ day $^{-1}$ during initial culture period (Table 3), but the growth

Table 3

Average daily growth of juvenile $H$. varia fed with three different diets

\begin{tabular}{llll}
\hline Period (days) & \multicolumn{2}{l}{ Average daily growth $[\mathrm{ADG}]$, shell length $(\mu \mathrm{m})$} & Ulva lactuca \\
\cline { 2 - 4 } & Coral red algae & Green filamentous algae & 88.000 \\
\hline $71-105$ & 80.853 & 29.147 & 33.000 \\
$106-138$ & 92.219 & 60.063 & 21.968 \\
$139-170$ & 33.226 & 51.563 & 25.069 \\
$171-200$ & 37.655 & 58.379 & \\
\hline
\end{tabular}


rate was higher in this trial in the final phase of rearing. Juveniles fed with $U$. lactuca had developed green and white colouration, whereas those fed with coralline red algae had reddish brown colour on their shells.

\section{Discussion}

In spite of the availability of rich marine fauna for mariculture, the coastal/marine aquaculture in India is dominated by shrimp culture. Although shrimp culture continues as a lucrative industry, recent setbacks attributed to the spread of white spot disease necessitated the development of alternative farming/mariculutre technologies and candidate species that could promise comparable profits to shrimp farming. Molluscan aquaculture is emerging in India as one of the viable alternatives to the continuously failing shrimp culture (Devaraj and Appukuttan, 2000). Aquaculture production of highly valuable abalone will enable us to place this species as a commodity in India's export basket, thereby increasing foreign exchange earnings. Once the seed production technique is standardised, the culture and pearl production in this species can be attempted in the country.

The results of the present experiment on the seed production of $H$. varia reveal that the larval production and rearing of this species are more or less similar to and within the time confines of other commercially important Haliotis species (Ebert and Houk, 1984; Genade et al., 1988; Capinpin and Hosoya, 1995). The spat of this species can be produced in a commercial scale, if the necessary requirements are provided. Breeding period of H. varia at Tuticorin extends from December to March (Najmudeen, 2001). Fully ripe abalones were only obtained 1 or 2 days before new moon or full moon days, and subsequent to this, most animals were in spent or partially spawned stage indicating mass spawning during this period in the natural habitat. Lunar periodicity has been reported in the top shell Trochus niloliticus by Hahn (1989).

Abalones with more advanced gonads were induced to spawn by desiccation method during natural spawning period. Two hours exposure to air resulted to massive spawning. When the animals were exposed to air immediately after transportation, high mortality due to stress was noted. The routine methods of spawning inducement, such as using hydrogen peroxide (Morse et al., 1979; Morse, 1984; Hooker and Morse, 1985) and UV irradiation (Kikuchi and Uki, 1974), were not tried in H. varia due to the success of the desiccation method. As reported in the tropical abalone Haliotis asinina (Capinpin and Hosoya, 1995), H. varia mostly spawned during evening or night hours, probably due to the lower temperature.

Male and female abalones were placed in the same container and the eggs were fertilised consequent to spawning. In most hatcheries, male and female abalones have been kept separately for spawning. Fertilisation was accomplished by mixing eggs and sperm (Kikuchi and Uki, 1974). However, Capinpin and Hosoya (1995) obtained good fertilisation rate following the technique used in the present study. The disadvantage of this method is the loss of control over the fertilisation process (Hahn, 1989). Fertilised eggs of H. varia are smaller $(180 \mu \mathrm{m})$ compared to that of Haliotis iris $(230 \mu \mathrm{m}$; Harrison and Grant, 1971) and Haliotis midae (222 $\mu \mathrm{m}$; Genade et al., 1988). 
Collection of ova from the spawning container and transfer of veligers to larval rearing containers are vital procedures during the hatchery phase as they can result in larval contamination. When eggs were kept in the spawning container for more than 1 $\mathrm{h}$ postspawning, the hatching rate was adversely affected. The same result was noticed by Ebert and Houk (1984) in Haliotis rufescens.

Trochophore and early veliger larvae of $H$. varia are phototactic as described in other haliotids by Koike (1978), Ebert and Houk (1984) and Pena (1986). Our larval rearing period ranged from 4 to 6 days at $27{ }^{\circ} \mathrm{C}$. The inverse relationship between the rearing period and water temperature has been reported (Ebert and Houk, 1984; Pena, 1986). The larvae of $H$. varia are lecithotropic as other abalone larvae.

One of the critical stages in the life history of invertebrate larvae occurs during the termination of planktonic stage (Slattery, 1992; Takahashi et al., 2002). In H. varia, complete larval settlement was achieved within the 7 th day of postfertilisation at $27{ }^{\circ} \mathrm{C}$. Larval settlement of Haliotis coccinea canariensis was in the 8th day of postfertilisation at $15{ }^{\circ} \mathrm{C}$ (Pena, 1975). In Haliotis discus hannai, the settlement process was initiated 6-7 days postfertilisation at $20{ }^{\circ} \mathrm{C}$ (Takami et al., 1997). Larvae periodically attached their foot to the walls of the container and crawled. Induced settlement and metamorphosis using a mat of diatoms were achieved in $H$. discus hannai (Seki and Kan-no, 1981) and $H$. rufescens (Slattery, 1992). Bryan and Qian (1998) reported that veliger larvae of Haliotis diversicolor were attached on diatom films, which was stimulated by certain species of bacteria within the films.

In their natural environment, abalone larvae settle exclusively on crustose red algae (Morse and Morse, 1984; Shepherd and Tumer, 1985). Spats of $H$. varia are seen on the rocks or coral pieces with coralline red algae. Morse et al. (1980) reported that GABAmimetic polypeptides sequestered from crustose red algae could be used as settlementinducing agents. No such chemical inducers were used in the present study. However, it was important to provide continuous supply of fresh diatom films for the settled and metamorphosed spats. Previous studies have suggested that the larvae are merely narcotised by compounds from diatom films or mucus trails of adults (Akashige et al., 1981), but the settlement observed mostly on the walls of the container in the present study clearly rules out this conclusion. As grazing by juveniles was vigorous, the diatom mat was cleaned up within short periods. Alternate exposure of the containers to sunlight helped maintain good diatom film.

The growth and survival of postlarvae are affected by the ingestibility and digestibility of the diatom which, in turn, depends on the species dominated in the biofilm (Roberts et al., 1999). Survival rates during the postsettlement period were generally low and variable (Searcy-Bernal et al., 1992). However, our experiments recorded about $70 \%$ survival through 50 days of rearing on the diatoms Nitzschia sp. and Navicula sp. Further detailed study is required on the ingestion efficiency of these diatoms for enhancing growth rate of postlarval $H$. varia. Takami et al. (1997) have reported that postlarval $H$. discus hannai reared on a diatom film containing Cocconeis scutellum var. parva grew for approximately 1 week, but were not able to grow after that and died before the end of 2 weeks. Roberts et al. (1999) reported that young postlarvae of $H$. asinina have high digestive efficiencies for two types of Navicula spp. 
Growth of juvenile abalone was enhanced at elevated temperatures. The fully formed first respiratory pore was observed within 27 days postfertilisation at $27{ }^{\circ} \mathrm{C}$. It was 8 weeks in $H$. rufescens at $15^{\circ} \mathrm{C}$ (Ebert and Houk, 1984) and 43 days in H. midae (Genade et al., 1988). Juveniles fed with crustose red algae had faster growth than those fed with the other two feeds. The major food of adult and juvenile $H$. varia is the coralline algae attached to coral stones. However, the average daily growth of $H$. asinina fed with Gracilariopsis heteroclada was two times higher than that obtained in the present study with coralline red algae (SEAFDEC, 1997). Juvenile shell colour is affected by the food consumed. Similar dietary pigmentation was observed in $H$. midae by Genade et al. (1988). This property can be utilised to produce quality abalone pearls by altering the iridescence of the shell interior.

The major advantage in the seed production of abalone is the nonrequirement of supplementary feeding during the larval rearing period, unlike many bivalve species which require suitable algal feed. The larval rearing period of $H$. varia is $4-6$ days, which reduces the possible risks associated with long periods of larval rearing. All of the other procedures are similar to the hatchery techniques of most of the other commercially important species of abalone. Findings of the present study are significant, as this would give insight in the production of abalone using only the naturally available diatom species for settlement and metamorphosis instead of expensive chemicals like GABA. The application of various strategies for induced maturation, spawning and settlement in $H$. varia would require further research to bring these process under complete control. The present study on the production of juveniles of $H$. varia in the hatchery may open up new avenues in the field of abalone culture and pearl production in India. Mass production of juveniles and ranching them on intertidal rocky coasts can further augment the natural population.

\section{Acknowledgements}

We are thankful to the Director of the Central Marine Fisheries Research Institute in Cochin for his constant encouragements and for providing necessary facilities. Thanks are also due to Dr. V. Kripa, senior scientist, Molluscan Fisheries Division, CMFRI, for critically correcting the manuscript. The study was financed by the Indian Council of Agricultural Research, New Delhi.

\section{References}

Akashige, S., Seki, T., Kan-no, H., Nomura, N., 1981. Effects of $\gamma$-amino butyric acid and certain neurotransmitters on the settlement and the metamorphosis of the larvae of Haliotis discus hannai Ino (Gastropoda). Bull. Tohoku Reg. Fish. Res. Lab. 43, 37-45.

Baudry, C.G., 1982. Survival and growth of the larvae of Haliotis kamtschatkana Jonas at different temperatures. Natl. Shellfish. Ass. 3 (1), 109.

Bryan, P.J., Qian, P.Y., 1998. Induction of larval attachment and metamorphosis in the abalone Haliotis diversicolor (Reeve). J. Exp. Mar. Biol. Ecol. 223, 39-51.

Capinpin, E.C., Hosoya, M., 1995. Spawning and larval development of a tropical abalone Haliotis asinina (Linne). Philipp. J. Sci. 124 (3), 215-232. 
Carlisle, J.G., 1945. The technique of inducing spawning in Haliotis rufescens Swainson. Science 102, 566.

Chen, H.C., 1989. Farming the small abalone, Haliotis diversicolor supertexta in Taiwan. In: Hahn, K.O. (Ed.), Hand Book of Culture of Abalone and Other Marine Gastropods. CRC Press, Boca Raton, FL, pp. 265-283.

Devaraj, M., Appukuttan, K.K., 2000. Perspective on coastal aquaculture in India. In: Pillai, V.N., Menon, N.G. (Eds.), Marine Fisheries Research and Management. CMFRI, Cochin, pp. 677-687.

Du, E.G., Guo, D.L., 1981. Preliminary study on the artificial breeding of Haliotis discus hannai Ino. J. Mar. Sci. 3, 25-27.

Ebert, E.E., Houk, J.L., 1984. Elements and innovations in the cultivation of red abalone Haliotis rufescens. Aquaculture 39, 375-392.

Genade, A.B., Hirst, A.L., Smith, C.J., 1988. Observations on the spawning, development and rearing of the South African abalone Haliotis midae Linn. S. Afr. J. Mar. Sci. 6, 3-12.

Hahn, K.O., 1989. Induction of settlement in competent abalone larvae. In: Hahn, K.O. (Ed.), Hand Book of Culture of Abalone and Other Marine Gastropods. CRC Press, Boca Raton, pp. 101-112.

Harrison, A.J., Grant, J.F., 1971. Progress in abalone research. Tasman. Fish. Res. 5 (1), 1.

Hooker, N., Morse, D.E., 1985. Abalone: the emerging development of commercial cultivation in the United States. In: Hunter, J.V., Brown, E.E. (Eds.), Crustacean and Molluscan Aquaculture in the United States. AVI Publishing, West port, Connecticut. 365 pp.

Iang, L.J., Moss, G.A., Redfeam, P., Illingworth, J., 1992. A manual of techniques for culturing paua, Haliotis iris, through to the early juvenile stage. N. Z. Fish. Tech. Rep. 31 (21 pp.).

Ino, T., 1952. Biological studies on the propagation of Japanese abalone (genus Haliotis). Bull. Tokai Reg. Fish. Res. Lab. 5 (102 pp.).

Jarayabhand, P., Paphavasit, N., 1996. A review of the culture of tropical abalone with special reference to Thailand. Aquaculture 140, 159-168.

Jarayabhand, P., Kojima, H., Menasveta, P., 1995. Embryonic and larval development of abalone, Haliotis ovina Gmelin. ARRI Newsl. 2 (1), 9-15.

Kawamura, T., 1996. The role of benthic diatoms in the early life stages of the Japanese abalone Haliotis discus hannai Ino. In: Watanbe, Y., Yamashita, Y., Oozeki, Y. (Eds.), Survival Strategies in Early Life Stages of Marine Resources. Balkema, Rotterdam, pp. 355-367.

Kikuchi, S., Uki, N., 1974. Technical study on artificial spawning of abalone, genus Haliotis: II. Effect of irradiated seawater with ultraviolet rays on inducing to spawn. Bull. Tohoku Reg. Fish. Res. Lab. 33, 79.

Koike, Y., 1978. Biological and ecological studies on the propagation of the ormer, Haliotis tuberculata Linnaeus: 1. Larval development and growth of juveniles. La Mer 16 (3), 124.

Leighton, D.L., 1972. Laboratory observation on the early growth of the abalone Haliotis sorensini and the effect of temperature on larval development and settling success. Fish. Bull. 70 (2), 373.

Morse, D.E., 1984. Biochemical and genetic engineering for improved production of abalones and other valuable molluscs. Aquaculture 39, 263-282.

Morse, D.E., 1990. Recent progress in larval settlement and metamorphosis: closing the gaps between molecular biology and ecology. Bull. Mar. Sci. 46 (2), 465-483.

Morse, A.N.C., Morse, D.E., 1984. Recruitment and metamorphosis of Haliotis larvae induced by molecule unequally available at the surfaces of crustose red algae. J. Exp. Mar. Biol. Ecol. 75, 191-215.

Morse, D.E., Hooker, N., Duncan, H., Jensen, L., 1979. Gamma amino butyric acid, a neurotransmitter, induces planktonic abalone larvae to settle and begin metamorphosis. Science 204, 407-410.

Morse, D.E., Tegner, M., Duncan, H., Hooker, N., Trevelyan, G., Cameron, A., 1980. Induction of settling and metamorphosis of planktonic molluscan (Haliotis) larvae: III. Signalling by metabolites of intact algae is dependant on contact. In: Muller-Schwarze, D., Silverstain, R.M. (Eds.), Chemical Signalling in Vertebrates and Aquatic Animals. Plenum, New York, pp. 67-86.

Najmudeen, T.M., 2001. Reproductive biology and seed production of the tropical abalone Haliotis varia Linnaeus (Gastropoda). PhD thesis. Central Institute of Fisheries Education, Mumbai, India. 238 pp.

Najmudeen, T.M., Victor, A.C.C., 2003. Annual reproductive cycle of the tropical abalone Haliotis varia Linnaeus in Mandapam waters of Gulf of Mannar. Book of Abstracts-First Indian Pearl Congress and Exposition, 5-8 February 2003. Central Marine Fisheries Research Institute, Cochin, pp. 88-90. 
Najmudeen, T.M., Ignatius, B., Victor, A.C.C., Chellam, A., Kandasami, D., 2000. Spawning, larval rearing and production of juveniles of the tropical abalone Haliotis varia Linn. Mar. Fish. Inf. Serv., Tech. Ext. Ser. $163,5-8$.

Nie, Z.Q., Chen, W.H., Ji, M.F., 1984. Studies on rearing conditions of abalone, Haliotis discus hannai Ino: 1. The effects of temperature and food on the growth of larvae and youngs. Mar. Fish. Res. 6, 35-40.

Pena, J.B., 1975. Preliminary study on the induction of the artificial spawning in Haliotis coccinea canariensis Nordsiek (1975). Aquaculture 52, 35.

Pena, J.B., 1984. Egg and larva development of Haliotis discus Reeve (Mollusca: Gastropoda Prosobranchia). Investig. Pesq. (Barc.) 48 (3), 441-454.

Pena, J.B., 1986. Preliminary study on the induction of artificial spawning in Haliotis coccinea canariensis Nordsiek (1975). Aquaculture 52, 35.

Roberts, R.D., Kawamura, T., Nicholson, C.M., 1999. Growth and survival of postlarval abalone (Haliotis iris) in relation to development and diatom diet. J. Shellfish Res. 18 (1), 243-250.

SEAFDEC, 1997. Abalone culture. Aquafarm news. SEAFDEC Asian Aquaculture 19 (2), $13-32$.

Searcy-Bernal, R., Salas-Garza, A.E., Flores-Aguilar, A., 1992. Research in Mexico on the critical stage of abalone (Haliotis spp.) seed production. In: Shephered, S.A., Tegner, M.J., Guzman del Proo, S.A. (Eds.), Abalone of the World: Biology, Fisheries and Culture. Fishing News Books, Oxford, pp. 547-560.

Seki, T., Kan-no, H., 1981. Induced settlement of the Japanese abalone, Haliotis discus hannai veliger by the mucous trails of the juvenile and adult abalones. Bull. Tohoku Reg. Fish. Res. Lab. 43, 29-36.

Shepherd, S.A., Tumer, J.A., 1985. Studies in Southern Australian abalone (genus: Haliotis): VI. Habitat preference, abundance and predators of juveniles. J. Exp. Mar. Biol. Ecol. 93, 285.

Slattery, M., 1992. Larval settlement and juvenile survival in the red abalone (Haliotis rufescens): an examination of inductive cues and substrate selection. Aquaculture 102, 143-153.

Snedecor, G.W., Cochran, W.G., 1967. Statistical Methods. Oxford and IBH Publishing, New Delhi, p. 172.

Strickland, J.D.H., Parsons, T.R., 1968. A practical handbook of seawater analysis. Bull. Fish. Res. Board Can. 16 (33 pp.).

Takahashi, Y., Itoh, K., Ishi, M., Suzuki, M., Itabashi, Y., 2002. Induction of larval settlement and metamorphosis of the sea urchin Strongyocentrotus intermedius by glycoglycerolipids from the green alga Ulvella lens. Mar. Biol. 140 (4), $763-771$.

Takami, H., Kawamura, T., Yamashitha, Y., 1997. Survival and growth of postlarval abalone Haliotis discus hannai fed on conspecific trail mucous and/or benthic diatoms Cocconeis scutellum var. parva. Aquaculture $152,129-138$.

Tong, L., 1982. Spawning and rearing of paua. Catch '82 9, 19.

Tong, I.J., Moss, G.A., Illingworth, J., 1987. Enhancement of natural population of the abalone Haliotis iris, using cultured larvae. Aquaculture 62 (1), 67-72.

Toole, C., 1988. Report of a study trip of Japan. IMolluscan Aquaculture and Fisheries. NOAA. University of California Cooperative Extension Program, California.

Walne, P.R., 1974. Culture of bivalve molluscs. 50 Years at Gonway. Fishing News (Books), West Byfleet. 173 pp. 